\title{
Microhabitat patterns of soft-bodied benthic algae in a lowland river largely fed by groundwater
}

\author{
Rossano BolPagni \& Alex LAINI
}

Life Sciences Department, University of Parma, Parco Area delle Scienze 11/A, I-43124 Parma, Italy; Corresponding author e-mail: rossano.bolpagni@unipr.it

\begin{abstract}
In lowland rivers largely fed by groundwater, the aquifer resurgence plays a major role in supporting local plant diversity. However, large knowledge gaps exist with regard the role of groundwater on algal diversity and spatial arrangement. In this context, our main aim was to evaluate the distributive gradients of soft-bodied benthic algae across a mid-size lowland river with a bottom dominated by hard substrate (Oglio River, north Italy). Along the investigated river sector, a clear segregation both for taxa and for environmental data was observed, especially in terms of $\mathrm{pH}$, hydrological variables and nutrient availability. Overall, we recorded an important contribution of groundwater supply in shaping the structure and complexity of algal communities at the microhabitat level (in the meter range) during the river base flow. All these considerations shed new light on the response of algal taxa to a relevant groundwater ingression in a lowland river.
\end{abstract}

Key words: algae, cyanobacteria, groundwater dependent ecosystems, spatial distribution, species diversity, hydrology, ecological determinants, nutrients

\section{INTRODUCTION}

The correct measurement and evaluation of distributive patterns of species represent a focal point in order to move from correlative to mechanistic relationships linking species diversity or abundance and environmental drivers (GELFAND et al. 2006). This is especially true for aquatic habitats, where the collection of data is very expensive and time-consuming (PASSY \& BLANCHET 2007), and it is even more for systems completely or partially fed by groundwater that exhibited typical isolated and point distributions and peculiar physicochemical mosaic conditions (LAINI et al. 2011).

All these systems are regarded as groundwater dependent ecosystems (GDEs) and include the aquatic water bodies whose extent and dynamics are dependent on groundwater supply, for example springs or wetlands originated by the emergence of groundwater aquifers (KLøve et al. 2011). GDEs play central roles in supporting both terrestrial and aquatic flora and fauna, especially during prolonged dry periods (KLøve et al. 2014; KuglerovÁ et al. 2014). This fundamental function (the provision of temporary refugees, often for rare or endemic taxa) is expected to be exacerbated and, at the same time, threatened by climate change (CANTONATI et al. 2012; KLøVE et al. 2014; JyväSJÄRVI et al. 2015). In this context, acquire information on the potential role of groundwater supply in supporting the algal diversity and spatial rearrangement could be of fundamental importance to outline plans for the preservation and enhancement of water use under different climatic scenarios.

Furthermore, despite the pivotal role played by algal communities in driving the river primary production, fundamental aspects such as species-area relationships, beta-diversity, and their interaction with habitat characteristics are still unexplored (PASSY \& BLANCHET 2007). This is especially true for the soft-bodied benthic algae of rivers, for which the relative importance of environmental factors in microhabitat structuring of their communities is yet largely missing (SCHNEIDER et al. 2013; RotT \& SCHNEIDER 2014). In this regard, a robust scientific literature is available only for diatoms (PAssy 2007; Kollár et al. 2015). Besides, given the central role assigned to the primary producer communities in the ecological assessment of aquatic ecosystems, these knowledge gaps can affect very negatively the quality evaluation of water bodies that is frequently done with limited sampling effort (LAINI et al. 2014).

Focusing on a mid-size river largely fed by groundwater, the resurgence of the aquifer could result in a clear physico-chemical zonation along the lateral gradient, with possible cascading effects on algal alpha-diversity and dominant taxa. We hypothesize that 
the transition from the riparian sectors (directly influenced by the groundwater resurgence) to the central river bed area (mainly affected by the river outflow) will deeply shape the composition and structure of algal communities. To test this prediction, an evaluation of the distribution and abundance gradients of soft-bodied benthic algae across a mid-size lowland river with a bottom dominated by hard substrate (Oglio River, north Italy) was performed. Specifically, we assessed the spatial arrangement of soft-bodied benthic algae across the entire riverbed in order to highlight the existence of floristic patterns and major physicochemical gradients.

\section{Material And Methods}

Study site. We collected data from the Oglio River (Lombardia, northern Italy), a mid-size man-regulated river with a total length of $154 \mathrm{~km}$ and a historical average discharge of $\sim 80 \mathrm{~m}^{3} . \mathrm{s}^{-1}$. It originates from the subalpine Lake Iseo (185 $\mathrm{m}$ a.s.l.) and flows into the Po River (16 $\mathrm{m}$ a.s.1.) crossing a heavily impacted catchment (of 3,840 $\mathrm{km}^{2}$ ), mainly devoted to agricultural activities (67\%) and animal farming (about 600,000 cows and over 2,100,000 pigs) (Bolpagni \& PiotTI 2015, 2016). Consequently, both surface and groundwaters were affected by appreciable nitrogen concentrations (LAINI et al. 2011; SoAnA et al. 2011). We focused our attention to the central rhithral sector of this river (of about $20 \mathrm{~km}$ ) that is characterized by relevant groundwater resurgence (Fig. 1). During summer time, in concomitance with an intense water abstraction for irrigation purposes, along this river sector the resurgence of groundwater represents about the $50 \%$ of the water discharge: a contribution of about $0.3-0.5 \mathrm{~m}^{3} \mathrm{~s}^{-1}$ of

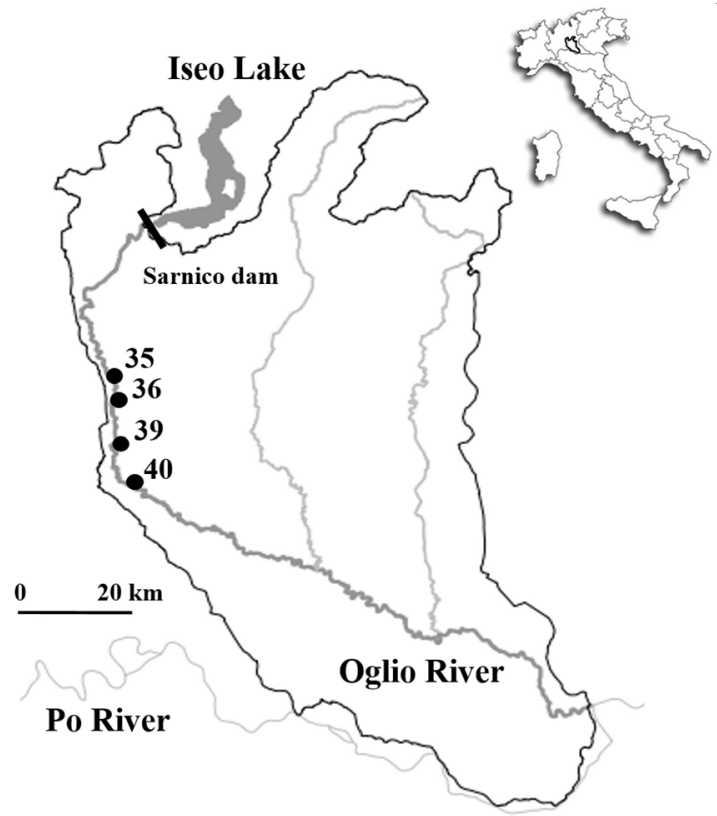

Fig. 1. Map of the Oglio River catchment with the location of sam-

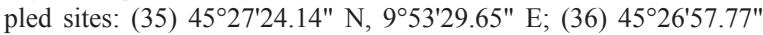

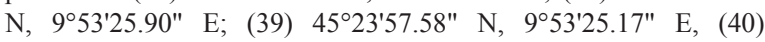
$45^{\circ} 20^{\prime} 17.88^{\prime \prime} \mathrm{N}, 9^{\circ} 54^{\prime} 14.73^{\prime \prime} \mathrm{E}$. groundwater per km was modeled (PTUA 2006). Four different homogenous river stretches of $100 \mathrm{~m}$ in length and $\sim 35$ $\mathrm{m}$ in section (number 35, 36, 39 and 40, Fig. 1) were investigated. They are spaced about $4-6 \mathrm{~km}$, and have the typical features of a lowland river, with gentle slopes and graveldominated substrates. During base flow conditions, the water depth ranged from few $\mathrm{cm}$ to up to $60 \mathrm{~cm}$.

Each site (the river stretch) was split into four different functional zones sensu BolPAGNI et al. (2013) in order to emphasize the existence of a gradual lateral influence of groundwater resurgence across riverbed. Accordingly, it was possible to clearly identify four different functional zones, namely: i) the lateral riverbed zones directly fed by groundwater (A), ii) the river' margin (close to the banks/cliffs (B), iii) the intermediate riverbed sector (equidistant from the riverbanks and the thalweg (C), and iv) the central river sector in correspondence to the thalweg (D) (Fig. 2). Conversely, these functional zones differed only minimally in terms of sediment type. They were largely characterized by pebbles and small boulders; exclusively the functional zone A exhibited a more fine-grained sediment dominated by a muddy sand matrix. During the sampling period, the river discharge was equal to $9.4 \mathrm{~m}^{3} \cdot \mathrm{s}^{-1}$ on average.

Algal characterization. During summer low-discharges 2013 (8-14 August), five random plots $(25 \times 25 \mathrm{~cm})$ for each functional zone per site were sampled (for a total number of 80 plots). At each sampling plot, presence and coverabundance values - collected using the geometrical classes $(0.14,0.28,0.56,1.1,2.2,4.4,8.8,18,35,71)$ provided by OKSANEN (1976) - of all visible soft-bodied benthic algal (= algal taxa including cyanobacteria attached to substrata in lotic and lentic waters, but excluding diatoms) growth form were recorded. All the different algal growth recognized in each plot were sampled, collecting a representative aliquot using tweezers, or by scraping 2-3 stones or pebbles. After an in situ rapid sorting of the sampled material, this was immediately fixed in $4 \%$ formaldehyde solution. Benthic algae were examined under a light microscope (100 to 400 or 1000 times magnification) and identified as close to species level as possible (EN 157082009 ) in agreement with several floras and monographs (e.g. KoMÁReK \& ANAGNOSTIDIS 1998, 2005; ELORANTA \& KWANDRANS 2007; JoHn et al. 2011). To obtain a reliable estimation of the cover-abundance values for the rare taxa 5 different slides (prepared proportionally to the cover-abundance values of the sampled algal forms) were analyzed for each sample plot. For the taxa of filamentous green algae that cannot be determined to the species level (Spirogyra and Mougeotia), categories based mainly on filament width were used (see SCHNEIDER \& LindSTRøM 2009 for further details).

Environmental characterization. Simultaneously to algal characterization, hydrological and physico-chemical data were collected at each sampled plot using standard procedures. Water depth and velocity were recorded by a flowprobe (FP111, Global Water's); using a portable multiprobe (YSI 556 MPS, YSI, Inc., Yellow Springs, Ohio) temperature, $\mathrm{pH}$, conductivity and oxygen concentration and saturation were measured. A water sample (about $250 \mathrm{ml}$ ) was collected by hand using a plastic bottle and filtered by GF/C filters (Whatman) and analyzed in lab for $\mathrm{NO}_{3}^{-}$and soluble reactive phosphorous $\left(\mathrm{PO}_{4}^{3-}\right)$ content. $\mathrm{NO}_{3}^{-}$was measured after reduction to $\mathrm{NO}_{2}^{-}$by activated cadmium, and then determined spectrophotometrically using sulphanilamide and 

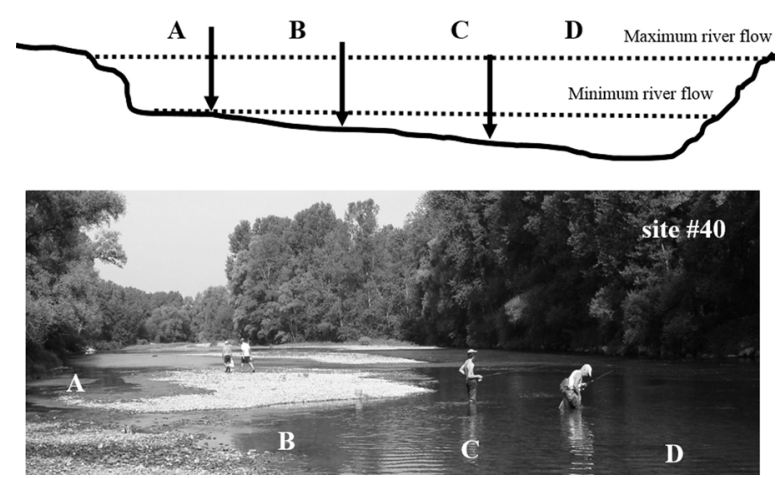

Fig. 2. Experimental design scheme: the figures illustrate the spatial distribution of the functional zones (A to D, see text for further specifications) across a sampled site (40) with respect to the water-atmosphere interface and the seasonal water-level fluctuations.

$\mathrm{N}-\left(1-\right.$ naphtyl)ethylendiamine (detection limit $\left.=50 \mu \mathrm{g} \cdot 1^{-1}\right)$ (Golterman et al. 1978). $\mathrm{PO}_{4}^{3-}$ was measured after reaction with ammonium molybdate and potassium antimonyl tartare and reduction by ascorbic acid (detection limit $=4 \mu \mathrm{g} \cdot \mathrm{l}^{-1}$ ) (VALDERRAma 1977). River discharges were kindly provided by the Consorzio dell'Oglio (Lombardy Region) in the frame of the project Evaluation of the Vital Minimum Flow of the Oglio River (2009-2015).

Statistical Analyses. A two-way ANOVA was performed to alpha-diversity (species richness) data to account for the relative effects of sites and functional zones, and for their interactions in $\mathrm{R}$ environment ( $\mathrm{R}$ Development Core Team 2014). To see which species, if any, would indicate the different functional zones investigated we performed the IndVal analysis based on cover-abundance data using the indicspecies package for $\mathrm{R}$ (De CÁceres \& Legendre 2009). The statistical significance of the taxa indicator values (IV) was evaluated using a randomization procedure (999 permutations). To explore the structure in our dataset we performed an nMDS on cover-abundance data. We use the Bray-Curtis dissimilarity distance to compute the resemblance matrix between functional zones. Linear fittings were performed between the environmental variables and the output of nMDS to identify the environmental factors driving the composition of benthic algae community (function envfit, vegan package, OKSANEN et al. 2011). For each fitting we calculated the squared correlation coefficients $\left(R^{2}\right)$ and $p$-values. In the $\mathrm{R}$ environment, we also tested the observed differences in species distribution patterns (based on cover-abundance values) among river' functional zones using Adonis (permutationbased multivariate analysis of variance) and Pairwise comparisons (R Development Core Team 2014).

\section{Results}

\section{River environment characterization}

All the investigated parameters showed a clear increase or decrease pattern moving from the lateral river functional zones inwards (from A to D). Changes were more pronounced at the turn of the lateral functional zones (A and B), while minor differences were record- ed between the inner ones (C and D) (Fig. 3).

Moving away from the functional zones A toward $\mathrm{D}$, a progressive increase in water depth and velocity was recorded, passing from depths and velocities of $20 \mathrm{~cm}$ and 0.0 feet $\mathrm{s}^{-1}$ to $50 \mathrm{~cm}$ and $0.9 \mathrm{~m} \cdot \mathrm{s}^{-1}$ on average, respectively (Fig. 3). Similarly, temperature, $\mathrm{pH}$ and oxygen peaked at the functional zone $\mathrm{D}$, with average values of $21^{\circ} \mathrm{C}, 7.6$, and $118 \%$, respectively. On the contrary, conductivity and $\mathrm{NO}_{3}^{-}$showed an opposite trend, with higher concentrations at the lateral zone A. Values varied in the range $405-820 \mu{\mathrm{S} . \mathrm{cm}^{-1}}^{-}$ and 3.3-12.0 mg..$^{-1}\left(\mathrm{NO}_{3}^{-}\right)$, respectively (Fig. 3). Compared to $\mathrm{NO}_{3}^{-}, \mathrm{PO}_{4}^{3-}$ exhibited an opposite tendency, almost doubling its average concentration (from 4.7 to $8.2 \mu \mathrm{g} . \mathrm{l}^{-1}$ ) passing from the lateral zone $\mathrm{A}$ to the inner one (D).

\section{Algal diversity, cover-abundance and distribution patterns}

Over the investigated river sector, a total of 28 taxa of soft-bodied benthic algae were recorded, the majority belonged to Chlorophyceae (10 taxa), Conjugatophyceae (5), Cyanophyceae and Ulvophyceae (both 4). In addition, few taxa of Xanthophyceae (2), Rhodophyceae (1), Pheophyceae (1) and Klebsormidiophyceae (1) were recorded (Table 1).

In terms of algal diversity, moving from the marginal functional zones to the inner part of the riverbed a progressive decrease in taxa number was noted. A maximum value of 26 taxa was recorded at functional zone B (equal to the $92.9 \%$ of the local diversity noted), whereas the lowest one was recorded at the functional zone D (16 taxa, equal to the $57.1 \%$ of the local diversity noted) (Table 1, Fig. 4). Generally, no statistical differences in $\alpha$-diversity were noted among sites (two-way ANOVA, $F=2.23, p=0.0932$ ), exclusively the functional zones (two-way ANOVA, $F=10.32, p$ $<0.001)$ and the interactions among the factors "sampling sites $x$ functional zones" (two-way ANOVA, $F=$ 2.30, $p=0.0261$ ) were statistically significant.

The most widespread taxa were Sphaerobotrys fluviatilis BuTCHER (found at 58 sites with a percentage frequency of $72.5 \%$ ), Cladophora glomerata (LINNAEus) KÜTZING (49, 61.3\%), Vaucheria cf. aversa HASSALL (42, 52.5\%), and Gongrosira fluminensis F.E.FRITSCH (41, 51.3\%). Cyanophyceae were scarcely represented with percentage frequencies in the range from $3.8 \%$ (Nostoc sp.) to $13.8 \%$ (Lyngbya cf. martensiana Meneghini ex Gomont); on the contrary, the unique species recorded for both Rhodophyceae [Hildenbrandia rivularis (LIEBMANN) J.AGARDH] and Pheophyceae [Heribaudiella fluvialis (AREschoug) Svedelius] shown intermediate frequency values equal to 47.5 and $43.8 \%$, respectively.

Regarding the taxa spatial distribution, several of them exhibited clear patterns showing a preference for one or more different riverbed sectors (Table 1). H. fluviatilis and $H$. rivularis were concentrated at 
Table 1. Algal distribution frequency (\%) for all plots together (tot), and for each functional river zone separately (A to D, see text and Fig. 2 for the further details). For the Mougeotia and Spirogyra taxa that cannot be classified at the species level, we adopted a descriptive classification based on cell width $(\mu \mathrm{m})$, number and spiraling density of chloroplasts $(2 \mathrm{~K}=$ two chloroplasts), and cell length/width ratio.

Taxon Frequency

$\begin{array}{lllll}\text { tot } & \text { A } & \text { B } & \text { C } & \text { D }\end{array}$

\section{Cyanophyceae}

Lyn_mar

Nos_sp1

Osc_lim

Ple_tom

\section{Rhodophyceae}

Hil_riv

Hildenbrandia rivularis

\section{Xanthophyceae}

Tri_vir

Vau_ave

\section{Phaeophyceae}

Her_flu

Heribaudiella fluviatilis

Tribonema viridis

Vaucheria cf. aversa

\section{Klebsormidiophyceae}

Kle_sp

Klebsormidium sp.

\section{Chlorophyceae}

Chae_inc

Dra_glo

Gon flu

Hyd_ret

Mic_abb

Oed_cal

Oed_cap

Sph_flu

Sti_ten

Tet_jav

\section{Ulvophyceae}

$\begin{array}{ll}\text { Cla_glo } & \text { Cladophora glomerata } \\ \text { Rhi_hie } & \text { Rhizoclonium hieroglyphicum } \\ \text { Ulo_aeq } & \text { Ulothrix aequalis } \\ \text { Ulo_zon } & \text { Ulothrix zonata }\end{array}$

Chaetophora incrassata

Draparnaldia glomerata

Gongrosira fluminensis

Hydrodictyon reticulatum

Microspora abbreviata

Oedogonium calcareum

Oedogonium capillare

Sphaerobotrys fluviatilis

Stigeoclonium cf. tenuis

Tetrasporidium javanicum

$\begin{array}{lllll}11.3 & - & 20.0 & 25.0 & - \\ 52.5 & 10.0 & 30.0 & 75.0 & 95.0\end{array}$

$\begin{array}{lllll}13.8 & 5.0 & 5.0 & 30.0 & 15.0 \\ 3.8 & - & 15.0 & - & - \\ 25.0 & 30.0 & 15.0 & 40.0 & 15.0 \\ 12.5 & - & 5.0 & 15.0 & 30.0\end{array}$

47.5

$100.0 \quad 15.0$

43.8

55.0

80.0

35.0

5.0
10.0

$\begin{array}{lllll}13.8 & 5.0 & 15.0 & 35.0 & - \\ 2.5 & 10.0 & - & - & - \\ 51.3 & 40.0 & 70.0 & 55.0 & 40.0 \\ 37.5 & 40.0 & 45.0 & 55.0 & 10.0 \\ 10.0 & 30.0 & 10.0 & - & - \\ 8.8 & 10.0 & 25.0 & - & - \\ 32.5 & 25.0 & 75.0 & 15.0 & 15.0 \\ 72.5 & 55.0 & 70.0 & 95.0 & 70.0 \\ 6.3 & - & - & - & 25.0 \\ 16.3 & 10.0 & 15.0 & 20.0 & 20.0\end{array}$

$\begin{array}{lllll}61.3 & 15.0 & 30.0 & 100.0 & 100.0 \\ 43.8 & 5.0 & 25.0 & 55.0 & 90.0 \\ 11.3 & 30.0 & 15.0 & - & - \\ 18.8 & 30.0 & 30.0 & 15.0 & -\end{array}$


Table 1 Cont.

\begin{tabular}{|c|c|c|c|c|c|c|}
\hline \multicolumn{7}{|c|}{ Conjugatophyceae } \\
\hline Mou_sp1 & Mougeotia sp. $(14-20 \mu \mathrm{m})$ & 10.0 & 30.0 & 10.0 & - & - \\
\hline Spi_sp1 & Spirogyra sp1 $(28-35 \mu \mathrm{m}, 2 \mathrm{~K}, 1 / \mathrm{b}>2)$ & 20.0 & 20.0 & 20.0 & 25.0 & 15.0 \\
\hline Spi_com & Spirogyra communis & 32.5 & 20.0 & 50.0 & 40.0 & 20.0 \\
\hline Spi_neg & Spirogyra neglecta & 31.3 & - & 30.0 & 55.0 & 40.0 \\
\hline Zyg_ste & Zygnema cf. stellinum & 12.5 & 35.0 & 15.0 & - & - \\
\hline$\alpha$-diversity & & 28 & 22 & 26 & 19 & 16 \\
\hline
\end{tabular}

the functional zone $\mathrm{B}$, with percentage frequencies of $80.0 \%$ and $100.0 \%$, respectively. A similarly result was recorded for $G$. fluminensis (with a percentage of $70.0 \%$ ). Conversely, the presence of C. glomerata, $V$. cf. aversa, and Rhizoclonium hieroglyphicum (C.AgARdH) KütZING peaked at the functional zones $\mathrm{C}$ and $\mathrm{D}$, with rates equal to $100 \%, 75.0-95.0 \%$, and 55.0-90.0\%, respectively (Table 1 ).

Cover-abundance values confirmed and better delineated the spatial patterns of taxa suggested by the distribution frequencies of algae (Tables 1, 2). Exclusively few taxa showed mean cover-abundance values higher than 0.5 ( 4 out 28 at the global scale, and 11 out 28 considering the four functional zones separately) (Table 2). Generally, the cover-abundance rates were low, not exceeding values of about 18; exclusively at the central sectors of the riverbed algae showed average values in the range 30.5-35.3. The most representative species was $C$. glomerata, with a mean coverabundance value of 11.9 , followed by $V$. cf. avers $a$ with a value of 3.9. C. glomerata dominated the functional zones D and C (in co-dominance with $V$. cf. aversa), Hydrodictyon reticulatum (LINNAEUS) BORY dominated the functional zone B (in co-dominance with $H$. rivularis), and finally $H$. rivularis dominated the functional zone A (in co-dominance with H. fluviatilis) (Table 2). All these evidences were further confirmed by the IndVal analysis. A total of 15 indicator species were identified (Table 3). Focusing on the most significant $(p<0.001)$, Zygnema $\mathrm{cf}$ stellinum (O.F.MüLLER) C.AgARDH (IV $=0.56)$ was identified as indicator species for the functional zone A, Oedogonium capillare KützING ex HIRN $(\mathrm{IV}=0.73)$ and $H$. rivularis $(\mathrm{IV}=$ $0.72)$ for $\mathrm{B}, V$. cf. aversa $(\mathrm{IV}=0.73)$ for $\mathrm{C}$, and $C$. glomerata $(\mathrm{IV}=0.81)$ and $R$. hieroglyphicum $(\mathrm{IV}=$ 0.70 ) for the zone D (Table 3 ).

The ordination maps obtained by nMDS analysis confirmed the existence of a clear segregation of taxa among functional zones, with the exception of zones A and B that are partially overlapped one another (Fig. 5). Exploring the correlation between nMDS outputs and environmental variables, all the variables considered showed statistically significant square coef- ficients. However, the most important variables were: $\mathrm{pH}\left(\mathrm{R}^{2}=0.82, \mathrm{p}<0.001\right), \mathrm{NO}_{3}^{-}\left(R^{2}=0.78, p<0.001\right)$, flow velocity $\left(R^{2}=0.76, p<0.001\right)$, conductivity $\left(R^{2}\right.$ $=0.74, p<0.001)$, water depth $\left(R^{2}=0.70, p<0.001\right)$, and $\mathrm{PO}_{4}{ }^{3-}\left(R^{2}=0.68, p<0.001\right)$. Oxygen and temperature displayed squared coefficients equal to 0.48 with a $p$-value of 0.015 . The Adonis results further underlined the marked differentiation between sites $(p<$ $0.001)$ and functional zones $(p<0.001)$ (Table 4$)$, emphasizing the predominant role of the functional zones (i.e. groundwater resurgence) which alone represented more than $38 \%$ of the explained variance. The Pairwise comparisons substantiated the existence of significant differences $(p<0.02)$ among all the functional zones combinations with the exception of the functional zone $\mathrm{A}$ in comparison to $\mathrm{B}(p=0.552)$. The total algal diversity remained constant among sites (as verified by two-way ANOVA analysis); however, the Adonis test suggested a rapid turnover in algal taxa among sites, as well as the existence of diversified algal communities in terms of cover-abundance values or species dominance.

\section{Discussion}

Summarizing, along the investigated river reach a clear segregation both for taxa and for environmental data was observed, especially in terms of relative taxa presence and cover-abundance, $\mathrm{pH}$, hydrological variables and nutrient availability. Overall, we observed an important contribution of groundwater supply in shaping the structure and complexity of algal communities at the microhabitat scale (in the meter range) during the summer river base flow. C. glomerata, R. hieroglyphicum and $V$. cf. aversa dominated the river's central zones $(\mathrm{D}+\mathrm{C})$ and were indicators of rather high $\mathrm{pH}$ values $(>7.2)$ and flow velocities of about $1.5 \mathrm{~m} . \mathrm{s}^{-1}$, and low $\mathrm{NO}_{3}^{-}$content $\left(3.7 \mathrm{mg} . \mathrm{l}^{-1}\right.$ in average). On the contrary, the marginal functional zones $(\mathrm{B}+\mathrm{A})$ exhibited a more diversified algal communities with the local dominance of $O$. capillare, $H$. rivularis and $Z$. cf. 
Table 2. Algal cover-abundance mean values - based on the geometric classes provided by OKSANEN 1976 - for all plots together (tot, $n$ $=80$ ), and for each functional river zone separately (A to D, see text for the further details; $n=20$ ); the number of colonized plots was reported in brackets. Only taxa with values $>0.5$ are shown; for the taxa abbreviations see Table 1.

\begin{tabular}{|c|c|c|c|c|c|}
\hline \multirow[b]{2}{*}{ Taxon } & \multicolumn{5}{|c|}{$\begin{array}{l}\text { Cover-abundance mean values } \\
(\mathrm{n}=\text { colonized plot })\end{array}$} \\
\hline & tot & $\mathbf{A}$ & B & $\mathbf{C}$ & D \\
\hline \multicolumn{6}{|c|}{ Rhodophyceae } \\
\hline Hil_riv & $\begin{array}{l}0.8 \\
(38)\end{array}$ & $\begin{array}{l}1.6 \\
(15)\end{array}$ & $\begin{array}{l}1.7 \\
(20)\end{array}$ & - & - \\
\hline \multicolumn{6}{|c|}{ Xanthophyceae } \\
\hline Vau_ave & $\begin{array}{l}3.9 \\
(42)\end{array}$ & - & - & $\begin{array}{l}10.9 \\
(15)\end{array}$ & $\begin{array}{l}4.1 \\
(19)\end{array}$ \\
\hline \multicolumn{6}{|c|}{ Phaeophyceae } \\
\hline Her_flu & $\begin{array}{l}0.6 \\
(33)\end{array}$ & $\begin{array}{l}1.1 \\
(11)\end{array}$ & $\begin{array}{l}1.1 \\
(14)\end{array}$ & - & - \\
\hline \multicolumn{6}{|c|}{ Chlorophyceae } \\
\hline Hyd_ret & $\begin{array}{l}1.3 \\
(30)\end{array}$ & $\begin{array}{l}1.2 \\
(8)\end{array}$ & $\begin{array}{l}2.0 \\
(9)\end{array}$ & $\begin{array}{l}1.9 \\
(11)\end{array}$ & - \\
\hline Mic_abb & - & $\begin{array}{l}0.6 \\
(6)\end{array}$ & - & - & - \\
\hline Oed_cap & - & - & $\begin{array}{l}0.7 \\
(15)\end{array}$ & - & - \\
\hline Sph_flu & $\begin{array}{l}1.2 \\
(58)\end{array}$ & $\begin{array}{l}0.7 \\
(11)\end{array}$ & $\begin{array}{l}1.9 \\
(14)\end{array}$ & $\begin{array}{l}1.6 \\
(19)\end{array}$ & - \\
\hline \multicolumn{6}{|c|}{ Ulvophyceae } \\
\hline Cla_glo & $\begin{array}{l}11.9 \\
(49)\end{array}$ & - & - & $\begin{array}{l}16.2 \\
(20)\end{array}$ & $\begin{array}{l}31.2 \\
(20)\end{array}$ \\
\hline Ulo_aeq & - & $\begin{array}{l}0.8 \\
(7)\end{array}$ & - & - & - \\
\hline \multicolumn{6}{|c|}{ Conjugatophyceae } \\
\hline Spi_com & - & - & $\begin{array}{l}0.6 \\
(10)\end{array}$ & - & - \\
\hline Zyg_ste & - & $\begin{array}{l}0.5 \\
(6)\end{array}$ & - & - & - \\
\hline
\end{tabular}

stellinum which were seen to act as indicators of rather high $\mathrm{NO}_{3}^{-}$content (up to $11.7 \mathrm{mg} . \mathrm{l}^{-1}$ ), low flow velocities $\left(<0.5 \mathrm{~m} \cdot \mathrm{s}^{-1}\right)$ and $\mathrm{pH}$ values (in the range 6.4-7.6). Indeed, $\mathrm{pH}, \mathrm{NO}_{3}^{-}$, water velocity and conductivity were the most important drivers in explaining the observed algal spatial patterns.

All these evidence are in line with previous works, highlighting the pivotal role played by the
Table 3. Indicator species for the four functional zones investigated (A to B; see text for further specifications); for the taxa abbreviations see Table 1 . The statistical significance $(P)$ of the indicator values (IVs) was texted using Monte Carlo permutation tests.

\begin{tabular}{|c|c|c|c|}
\hline Functional zone & IV & $P$ & \\
\hline \multicolumn{4}{|l|}{$\mathbf{A}$} \\
\hline Zyg_ste & 0.56 & 0.0008 & $* * *$ \\
\hline Ulo_aeq & 0.53 & 0.0027 & ** \\
\hline Mou_sp1 & 0.52 & 0.0032 & ** \\
\hline Mic_sp. & 0.47 & 0.0090 & ** \\
\hline Ulo_zon & 0.46 & 0.0499 & * \\
\hline \multicolumn{4}{|l|}{ B } \\
\hline Oed_cap. & 0.73 & 0.0001 & $* * *$ \\
\hline Hil_riv & 0.72 & 0.0001 & $* * *$ \\
\hline Spi_com & 0.59 & 0.0052 & ** \\
\hline Her_flu & 0.59 & 0.0047 & ** \\
\hline Oed_cal & 0.44 & 0.0286 & * \\
\hline \multicolumn{4}{|l|}{$\mathbf{C}$} \\
\hline Vau_ave & 0.73 & 0.0006 & $* * *$ \\
\hline Chae_inc & 0.51 & 0.0058 & $* *$ \\
\hline \multicolumn{4}{|l|}{ D } \\
\hline Cla_glo & 0.81 & 0.0001 & $* * *$ \\
\hline Rhi_hie & 0.70 & 0.0001 & $* * *$ \\
\hline Sti_ten & 0.50 & 0.0023 & $* *$ \\
\hline
\end{tabular}

physico-chemical determinants in shaping river benthic algal assemblages, but not confirm a lesser importance of $\mathrm{NO}_{3}^{-}$and conductivity than $\mathrm{P}$ (SCHENIDER et al. 2013; RotT \& Schenider 2014). This is probably due to the relative diffuse nitrate contamination of groundwater and the importance of aquifer resurgence in fed surficial water bodies in the studied area. The locally high $\mathrm{NO}_{3}^{-}$contamination makes difficult to explain the natural groundwater $\mathrm{NO}_{3}{ }^{-}$content, as highlighted by LiMBRICK (2003) in the south Dorset (UK), and can blind the importance of the other ecological determinants in driving algal assemblages. However, in total agreement with those by GARcíA \& ABOAL (2014) for the Pego-Oliva marsh (East Iberian Peninsula), our data confirm the presence of well-diversified soft-bodied benthic algal communities under unusually high nitrogen concentrations. This suggests the probably existence of adaptation processes in the establishment and development of algae in heavily impacted floodplains. Similar evidences were recorded by BoLPAGNI et al. (2015) investigating the spatial distribution of Thorea hispida (Thore) Desvaux along the Oglio River. Another important element can be traced in part to the 

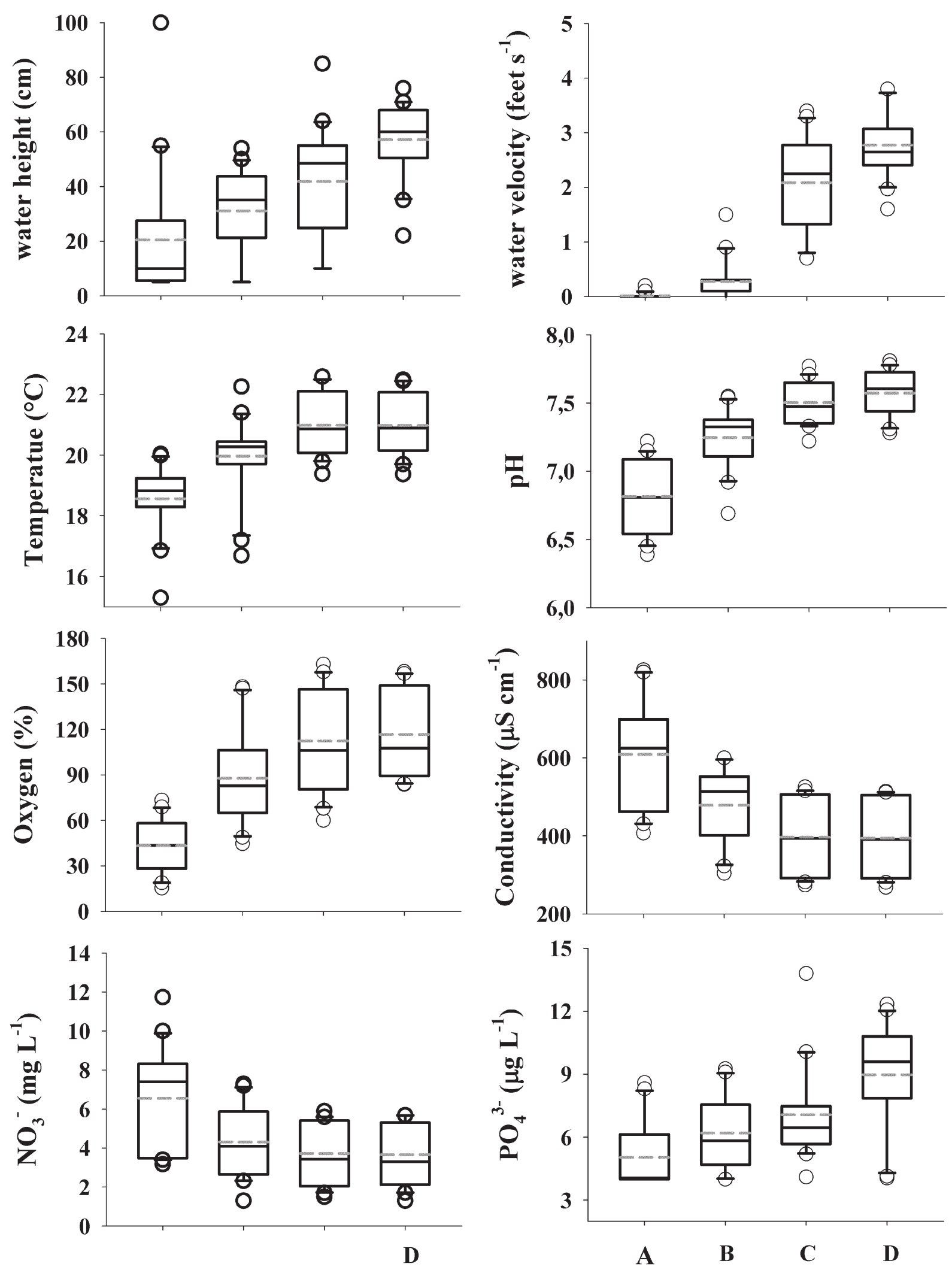

Fig. 3. Box-whiskers plots (minimum, 25\%, median, mean = grey dashed line, $75 \%$, maximum, and outliers $=$ dots) showing variability in water depth, water velocity, temperature, $\mathrm{pH}$, oxygen, conductibility, $\mathrm{NO}_{3}{ }^{-}$and $\mathrm{PO}_{4}{ }^{3-}$ concentrations at the four different river functional zones investigated (A, B, C, and D); see text for further specifications. 


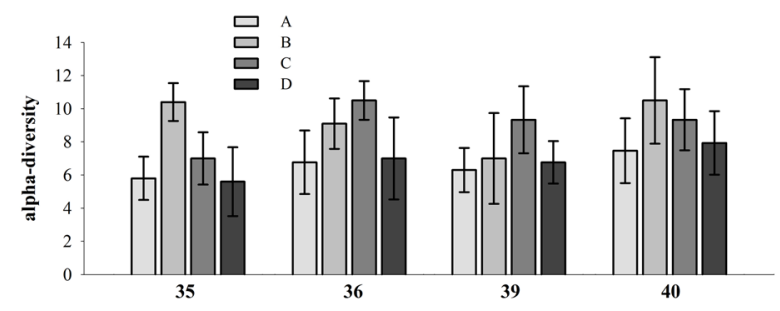

Fig. 4. Algal diversity (mean \pm standard deviation; $n=5$ ) at the functional zone scale (A to D; see text for further specifications).

Table 4. The results of the Adonis analysis used to test the direct effects of sites (S) and functional zones (FZ) on the taxa composition of algal communities $[(D f)$ degrees of freedom; $(S S)$ sum of squares; $(E V)$ explained variance $(\%) ;(M S)$ mean squares; $(F) F$-statistic; (p) $p$-value based on permutations].

\begin{tabular}{lllllll}
\hline & $\boldsymbol{D} \boldsymbol{f}$ & $\boldsymbol{S S}$ & $\boldsymbol{M S}$ & $\boldsymbol{E v}$ & $\boldsymbol{F}$ & $\boldsymbol{p}$ \\
\hline S & 3 & 2.47 & 0.82 & 9.5 & 6.76 & $<0.0001$ \\
FZ & 3 & 10.35 & 3.45 & 39.8 & 28.37 & $<0.0001$ \\
St x FZ & 9 & 5.41 & 0.60 & 20.8 & 4.94 & $<0.0001$ \\
Residuals & 64 & 7.78 & 0.12 & & 0.30 & \\
Total & 79 & 26.00 & 1 & & & \\
\hline
\end{tabular}

riverbed microhabitat complexity. As stressed by KRUPEK et al. (2012) sampling different streams in the Brazilian subtropical region, the macroalgal community structure seems to be strictly driven by the microhabitat variables, especially in term of substrate type. However, in our system, moving from the functional zone A to $\mathrm{D}$, the substrate changed only moderately from a predominantly muddy-sandy character with small pebbles (A) to an hard one co-dominated by pebbles and small boulders (B to D). Consequently, we do not believe that the gradient in substrate structure can justify the significant differences observed in terms of algal diversity and cover-abundance. In this context, the influence of groundwater supply in supporting algal diversity should be further investigated. Indeed, $\mathrm{KU}$ GLEROVÁ et al. (2014) considering the riparian river sectors of rivers largely fed by groundwater demonstrated the strong positive role of water resurgence on local plant diversity. The increase in soil $\mathrm{pH}$ as well as of the nitrogen availability (manifested as lower soil $\mathrm{C} / \mathrm{N}$ ratio) associated to the aquifer resurgence were considered the main drivers of this species number increase. Present data support this evidence and stress the importance of groundwater supply in the spatial patterns of riverine primary producers.

Our data support also the not-negligible contribution of the hydrological features (flow velocity and water depth) in driving the spatial arrangement of algae across a riverbed, as widely expected for other fundamental river biological communities (GUARESCHI et al. 2014). These factors are normally neglected in the field surveys and monitoring programs based on algae. However, several evidences have suggested the central role of water flow dynamics on algal establishment and development, especially in impacted and regulated watercourses (VILLENEUVE et al. 2011). For example, investigating the spatial patterns of filamentous green algae in a large fluvial lake (Lake Saint-Pierre, Canada), CATteneo et al. (2013) verified the predominance of the hydrological variables as predictors of algae occurrence and no effect of water quality. Similarly, ANDRUS et al. (2015) verified the pivotal contribution of both water flow and velocity in influencing the assemblage structure of algae in agricultural streams (Midwest, USA). Many authors have also stressed the contributions (both positive and negative) of fluctuations in current velocity in determining the characteristics of fixed algae communities. These effects may be summarized in an increase in nutrient delivery and a greater oxygenation of water, or in the abrasive mechanical effects of water flow (BRANCO \& NECCHI JÚNIOR 1997). With respect to the potential filtering effect of shading on algae diversity and their spatial distribution (STEINMAN \& MCINTIRE 1987), along the Oglio River reach analysed it could be considered marginal. Exclusively at the functional zone A the shading could reach values of $20 \%$; in general, shading values constantly in the range 0 to $5 \%$ were recorded.

All these reflections acquire enhanced emphasis considering the central role assigned to the macro-algae in the monitoring programs of river health. Hence, based on the evaluation reported by HAURY et al. (2006), among the species recorded along the Oglio River, some can be considered quite good indicators of well-oxygenated and clear waters. $H$. rivularis and the genera Mougeotia, Tetraspora and Zygnema show a water quality score (Csi) higher than 12 in a scale of 0 (heavy organic pollution and heterotrophyc taxa) to 20 (oligotrophy). These evaluations contrast in part with the current physico-chemical quality status of the Oglio River as well as the N surplus generated in its catchment (SOANA et al. 2011). A possible explanation is that these taxa, generally found in the lateral functional zones of the sites investigated, seem to be more driven by the temperature or the imbalance in the $\mathrm{C}: \mathrm{N}: \mathrm{P}$ ratio than the chemical determinants availability per se. In fact, the above-mentioned taxa are not typical of lowland rivers but of low order watercourses (streams) in mountain regions, especially $H$. rivularis (SHEATH \& Hambrook 1990). Abdelahad et al. (2015) recorded similar results by surveying a large set of lowland freshwater springs located in a narrowed heavily impacted floodplain area $(30 \times 12 \mathrm{~km})$, largely placed within the Oglio River basin. They revealed a marked difference in the physical and chemical preferences of Batrachospermales applying a niche analysis approach, suggesting a major role for $\mathrm{NO}_{3}^{-}$in the appearance of morphological deformities in the red algal 

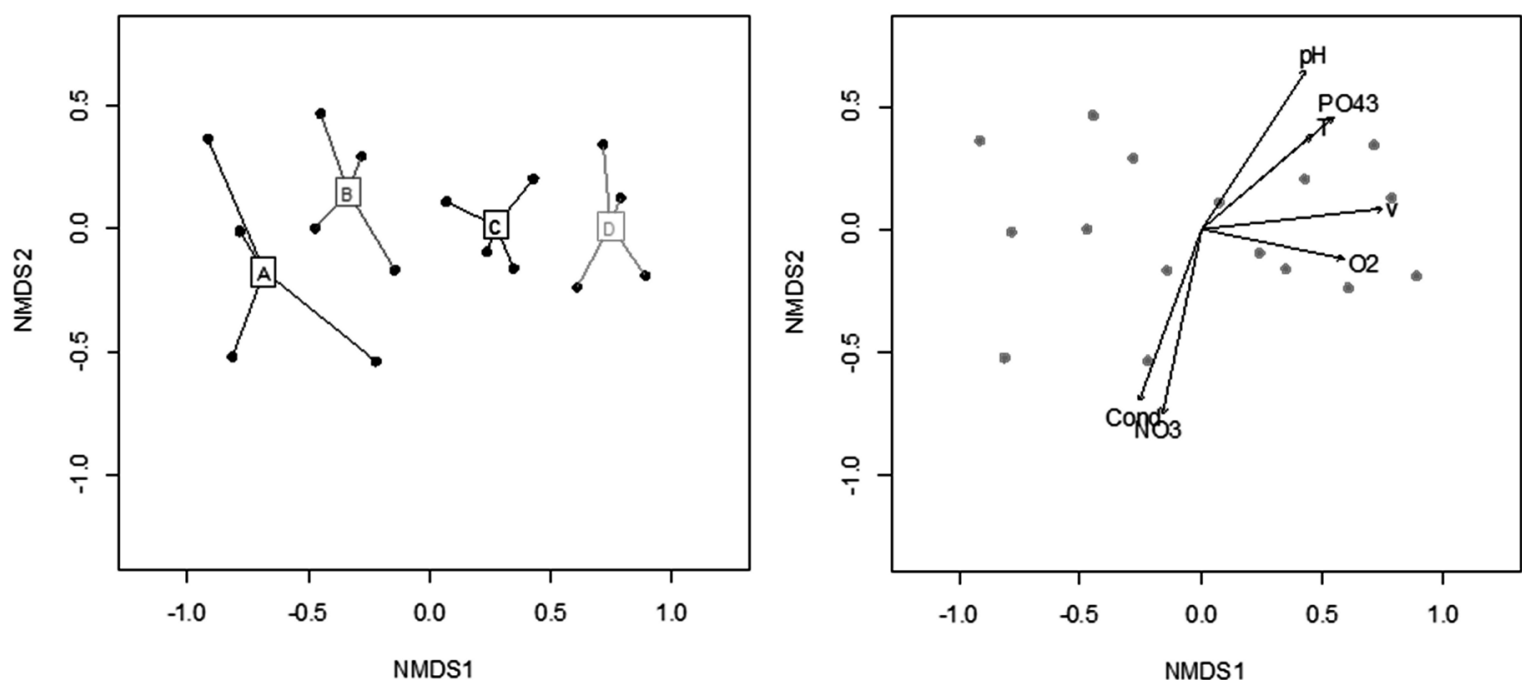

Fig. 5. Non-metric multidimensional scaling (NMDS) ordination of algal communities in a two-dimensional space. The left plot combines individual sample plots with the average score of each functional zone (A to D; see text for further specifications). In the right plot, the environmental vectors have been fitted onto the ordination diagram (see Table 4 for abbreviation and details).

reproductive structures. Furthermore, the widespread occurrence of red algae in presence of rather cold and impacted waters, with $\mathrm{NO}_{3}^{-}$concentrations in the range 19.1-53.6 mg. $1^{-1}$, was mainly associated by the stoichiometric imbalance among nutrients. Locally, in the emergent groundwater the dissolved reactive phosphorus was completely absent due to the trapping by the soil-matrix groundwater system.

The present data integrate previous works on the importance of spatial variables in shaping benthic algal communities (TANG et al. 2013), introducing a non-negligible role of micro-scale features of riverbeds in supporting the patchiness of algal mats. In a few meters, we recorded a clear succession of algal communities in presence of wide variations in terms of hydrological and physico-chemical determinants (such as $\mathrm{pH}, \mathrm{NO}_{3}{ }^{-}$and conductivity). However, at the site scale the two-way ANOVA and Adonis analyses have shown contrasting results, suggesting the existence of multiple forces and complex interactions in shaping the algal communities (both in terms of species diversity and abundance). A possible explanation may be the rapid variation (in space) in the magnitude of groundwater supply (in terms of $\mathrm{NO}_{3}^{-}$availability) along the river sector in analysis.

All these considerations shed also new light on the response of algal taxa to a relevant groundwater ingression in a lowland river. This phenomenon is capable of creating steep gradients along the lateral spatial dimension of the river and can profoundly influence the multidimensional interactions between the river channel and its catchment. Furthermore, our data suggest the need for an appropriate definition of spatial scales in order to a correct assessment of the trophic requirements of algal taxa as stressed by TANG et al. (2013). We would like to reiterate the need to join regional studies (i.e. macro-scale investigations) with depth analyses on the micro-spatial gradients. Only in this way, it will be possible obtain a proper ecological assessment of individual species taking into account their adaptability to changes in the trophic conditions of water bodies colonized.

\section{ACKNOWLEDGements}

This research was partially supported by Consorzio dell'Oglio (Lombardy Region) in the frame of the project Evaluation of the Vital Minimum Flow of the Oglio River (2009-2012). We are grateful to Ing. M. Buizza for his technical and field support.

\section{REFERENCES}

Abdelahad, N.; Bolpagni, R.; Jona Lasinio, G.; Vis, M.L.; Amadio, C.; Laini, A. \& KeIL, E.J. (2015): Distribution, morphology and ecological niche of Batrachospermum and Sheathia species (Batrachospermales, Rhodophyta) in the fontanili of the Po plain (northern Italy). - European Journal of Phycology 50: 318-329.

Andrus, J.M.; Winter, D.; Scanlan, M.; Sullivan, S.; BollMAN, W.; WagGoner, J.B.; Hosmer, A.J. \& Brain, R.A. (2015): Spatial and temporal variation of algal assemblages in six Midwest agricultural streams having varying levels of atrazine and other physicochemical attributes. - Science of the total environment 505: 65-89.

Bolpagni, R. \& Piotti, A. (2015): Hydro-hygrophilous vegetation diversity and distribution patterns in riverine wetlands in an agricultural landscape: a case study from the Oglio River (Po plain, Northern Italy). Phytocoenologia 45: 69-84.

Bolpagni, R. \& Piotti, A. (2016): The importance of being natural in a human-altered riverscape: role of wetland type in supporting habitat heterogeneity and the functional diversity of vegetation. - Aquatic Conservation: Marine and Freshwater Ecosystems: DOI: 10.1002/aqc.2604. 
Bolpagni, R.; Bartoli, M. \& Viaroli, P. (2013): Species and functional plant diversity in a heavily impacted riverscape: Implications for threatened hydro-hygrophilous flora conservation. - Limnologica 43: 230-238.

Bolpagni, R.; Amadio, C.; Johnston, E.T. \& Racchetti, E. (2015): New physical and chemical perspectives on the ecology of Thorea hispida (Thoreaceae). - Journal of Limnology 74: 294-301.

Branco, L.H.Z. \& NeCCHI JÚNIOR, O. (1997): Seasonality of macroalgae in three tropical drainage basins in São Paulo State, southeastern Brazil. - Archiv fur Hydrobiologie 141: 75-91.

Cantonati, M.; Fureder, L.; Gerecke, R.; Juttner, I. \& Cox, E.J. (2012): Crenic habitats, hotspots for freshwater biodiversity conservation: toward an understanding of their ecology. - Freshwater Science 31: 463-480.

Cattaneo, A.; Hudon, C.B.; Vis, C. \& Gagnon, P. (2013): Hydrological control of filamentous green algae in a large fluvial lake (Lake Saint-Pierre, St. Lawrence River, Canada). - Journal of Great Lakes Research 39: 409-419.

Gelfand, A.E.; Silander, JR. J.A.; Wu, S.; Latimer, A.; LeWis, P.O.; Rebelo, A.G. \& Holder, M. (2006): Explaining Species Distribution Patterns through Hierarchical Modeling. - Bayesian Analysis 1: 41-92.

Laini, A.; Bartoli, M.; Castaldi, S.; Viaroli, P.; Capri, E. \& Trevisan, M. (2011): Greenhouse gases $\left(\mathrm{CO}_{2}, \mathrm{CH}_{4}\right.$ and $\mathrm{N}_{2} \mathrm{O}$ ) in lowland springs within an agricultural impacted watershed (Po River plain, northern Italy). - Chemistry and Ecology: 27: 177-187.

Laini, A.; Vorti, A.; Bolpagni, R. \& Viaroli, P. 2014. Smallscale variability of benthic macroinvertebrates distribution and its effects on biological monitoring. - Annales de Limnologie - International Journal of Limnology 50: 211-216.

LimBrick, K.J. (2003): Baseline nitrate concentration in groundwater of the Chalk in south Dorset, UK. - Science of the Total Environment 314-6: 89-98.

De Cáceres, M. \& Legendre, P. (2009): Associations between species and groups of sites: indices and statistical inference. - Ecology 90: 3566-3574.

Eloranta, P. \& Kwandrans, J. (2007): Freshwater red algae Rhodophyta. Identification guide to European taxa, particularly to those found in Finland. - Norrlinia 15: $1-103$.

EN 15708 (2009): Water quality - guidance standard for the surveying, sampling and laboratory analysis of phytobenthos in shallow running water. - Comité Européen de Normalisation, Brussels.

García, M.E. \& ABoAl, M. (2014): Environmental gradients and macroalgae in Mediterranean marshes: the case of Pego-Oliva marsh (East Iberian Peninsula). - Science of the Total Environment 475: 216-224.

Golterman, H.L.; Clymo, R.S. \& Ohnstand, M.A.A. (1978): Methods for physical and chemical analysis of freshwaters, Handbook No. 8. - 213 pp., I.B.P., Blackwell.

Guareschi, S.; Laini, A.; Racchetti, E.; Bo, T.; Fenoglio, S. \& Bartoli, M. (2014): How do hydromorphological constraints and regulated flows govern macroinvertebrate communities along an entire lowland river? - Ecohydrology 7: 366-377.

Haury, J.; Peltre, M.-C.; Trémolières, M.; Barbe, J.; Thiébaut, G.; Bernez, I.; Daniel, H.; Chatenet, P.; HaAn-Archipof, G.; Muller, S.; Dutartre, A.; Laplace-Treyture, C.; Cazaubon, A. \& Lambert-Ser-
VIEN, E. (2006): A new method to assess water trophy and organic pollution - The Macrophyte biological index for rivers (IBMR): Its application to different types of river and pollution. - Hydrobiologia 570: $153-158$.

Jyväsjärvi, J.; Marttila, H.; Rossi, P.M.; Ala-Aho, P.; Olofsson, B.; Nisell, J.; Backman, B.; Ilmonen, J.; Virtanen, R.; Paasivirta, L.; Britschgi, R.; Kløve, B. \& MuotкA, T. (2015). Climate-induced warming imposes a threat to north European spring ecosystems. - Global Change Biology 21: 4561-4569.

John, D.M.; Whitton, B.A. \& Brook, A.J. (2011): Freshwater algal flora of the British Isles. -878 pp., The Natural History Museum and The British Phycological Society, Cambridge University Press.

Kløve, B.; Ala-Aho, P.; Bertrand, G.; Boukalova, Z.; ERTÜRK, A.; Goldscheider, N.; Ilmonen, J.; KaraKaya, N.; Kupfersberger, H.; Kverner, J.; LundBerg, A.; Mileusnić, M.; Moszczynska, A.; MuotKa, T.; Preda, E.; Rossi, P.; Siergieiev, D.; ŠimeK, J.; WachNiew, P.; Angheluta, V. \& Widerlund, A. (2011): Groundwater dependent ecosystems. Part I: Hydroecological status and trends. - Environmental Science and Policy 14: 770-781.

Kløve, B.; Ala-Aho, P.; Bertrand, G.; Gurdak, J.J.; Kupfersberger, H.; Kverner, J.; Muotka, T.; Mykrä, H.; Preda, E.; Rossi, P.; Uvo, C.B.; Velasco, E. \& Pulido-Velazquez, M. (2014): Climate change impacts on groundwater and dependent ecosystems. Journal of Hydrology 518: 250-266.

Kollár, J.; Fránková, M.; Hašler, P.; Letáková, M. \& PoulíčKovÁ, A. (2015): Epiphytic diatoms in lotic and lentic waters - Diversity and representation of species complexes. - Fottea 15: 259-271.

KomÁreK, J. \& AnAgnostidis, K. (1998): Cyanoprokaryota I. - In: Ettl, H.; GÄrtner, G.; Heynig, H. \& MolLENHAUER, D. (eds): Süßwasserflora von Mitteleuropa, Band 19/1. - 548 pp., Gustav Fischer Verlag, Stuttgart - Jena.

KomáreK, J. \& Anagnostidis, K. (2005): Cyanoprokaryota 2. - In: Ettl, H.; Gärtner, G.; Heynig, H. \& MolLENHAUER, D. (eds): Süsswasserflora von Mitteleuropa Band 19/2. - 759 pp., Gustav Fischer Verlag, Stuttgart - Jena.

Krupek, R.A.; Zanini Branco, C.C. \& Peres, C.K. (2012): Spatial variations at different observational scales and the seasonal distributions of stream macroalgae in a Brazilian subtropical region. - Brazilian Journal of Botany 35: 249-257.

Kuglerová, L.; Jansson, R.; Ågren, A.; Laudon, H. \& MALM-RenÖFÄLt, B. (2014): Groundwater discharge creates hotspots of riparian plant species richness in a boreal forest stream network. - Ecology 95: 715725 .

OKsanen, L. (1976): On the use of the Scandinavian type class system in cover estimation. - Annales Botanici Fennici 13: 149-153.

Oksanen, J.; Blanchet, F.G.; Kindt, R.; Legendre, P.; Minchin, P.R.; O'Hara, R.B.; Simpson, G.L.; Solymos, P.; Stevens, M.H.H. \& Wagner, H. (2011): Vegan: Community Ecology Package. R package version 2.0-0 [online]. -http://CRAN.R-project.org/ package $=$ vegan.

PAssy, S.I. (2007): Diatom ecological guilds display distinct and predictable behavior along nutrient and distur- 
bance gradients in running waters. - Aquatic Botany 86: $171-178$.

Passy, S.I. \& Blanchet, F.G. (2007): Algal communities in human-impacted stream suffer beta-diversity decline. - Diversity and Distributions 13: 670-679.

PTUA (2006): Programma regionale di Tutela e Uso delle Acque. - Lombardy Region, Milan.

R Development Core Team. (2014): A language and environment for statistical computing. - R Foundation for Statistical Computing, Wien.

RotT, E. \& SchNeIDER, S.C. (2014): A comparison of ecological optima of soft-bodied benthic algae in Norwegian and Austrian rivers and consequences for river monitoring in Europe. - Science of the Total Environment 475: 180-186.

Schneider, S.C. \& LindstrøM, E.-A. (2009): Bioindication in Norwegian rivers using nondiatomaceous benthic algae: the acidification index periphyton (AIP). Ecological Indicators 9: 1206-1211.

Schneider, S.C.; Kahlert M. \& Kelly, M. (2013): Interactions between $\mathrm{pH}$ and Nutrients on Benthic Algae in Streams and Consequences for Ecological Status Assessment and Species Richness Patterns. - Science of the Total Environment 444: 73-84.

Sheath, R.G. \& Hambrook, J.A. (1990): Freshwater ecology. - In: Cole, K.M. \& Sheath, R.G. (eds): Biology of red algae. - pp. 423-453, Cambridge University Press, Cambridge.

Soana, E.; Racchetti, E.; Laini, A.; Bartoli M. \& Viaroli, P. (2011): Soil budget, net export, and potential sinks of nitrogen in the lower Oglio River watershed (northern Italy). - CLEAN 39: 956-965.

Steinman, A.D. \& McInTiRe, C.D. (1987): Effects of irradiance on the community structure and biomass of algal assemblages in laboratory streams. - Canadian Journal of Fisheries and Aquatic Sciences 44: 16401648.

TAnG, T.; Wu, N.; Li, F.; Fu, X. \& CAI, Q. (2013): Disentangling the roles of spatial and environmental variables in shaping benthic algal assemblages in rivers of central and northern China. - Aquatic Ecology 47: 453-466.

VALDERRAMA, J.C. (1977): Methods used by the Hydrographic Department of the National Board of Fisheries, Sweden. - In: Grasshof, K. (ed.): Report of the Baltic Intercalibration Workshop. Interim Commission for the Protection of the Environment of the Baltic Sea, Annex. - pp. 13-40, Goteborg.

Villeneuve, A.; Bouchez, A. \& Montuelle, B. (2011): In situ interactions between the effects of season, current velocity and pollution on a river biofilm. Freshwater Biology 56: 2245-2259.

(C) Czech Phycological Society (2016)

Received January 11, 2016

Accepted March 21, 2016 